\title{
Post-Secondary Education in the Prison: Cognitive and Moral Development or Social Control? Brian D. MacLean
}

The task of educational programming as rehabilitation demands a preparation of the prisoner for eventual participation outside following his/her release. With few exceptions prison education is described as personal development: the acquisition of skills/knowledge which will be useful in getting a job, developing a new world view, and above all else staying out of trouble. The question which I should like to pose is this: Should this form of educational programming be seen as a form of personal development or as a form of social control?

The question is not a simple one and the answer may be even more complex. In order to answer it, I will briefly examine the history of educational programming in the Canadian prison system. Then by focusing on one post-secondary educational program in that system, I will discuss the theoretical perspective of criminal behavior on which this programming is based, its accomplishments, and its implications as a form of social control.

When Kingston penitentiary first opened its doors in 1835, the penal philosophy of the time included a strict regime of sanitation, inspection, separate confinement, sobriety, coarse diet, hard labor, and a rough and uniform apparel. The emphasis was on retribution not rehabilitation, and a silent system was strictly enforced. Prisoners spent from twelve to sixteen hours a day in their cells, and no leisure activities of any sort were allowed. Although prisoners were compelled to attend church on Sundays, they were not allowed to have any contact with other prisoners. During the ninteenth century, a teacher was employed to provide individual instruction in cells during evening hours. The emphasis was on basic literacy for a few prisoners; not a functional literacy for all (MacGuigan, 1977).

The period of 1900 to 1960 saw a change in penal philosophy from a retributive to a rehabilitative model, and a number of changes in penal practice concomitant with this philosophical shift occurred (Ekstadt and Griffiths, 1988). Lighting was placed in cells to enable prisoners to read and study during daylight hours - at first as a reward for good conduct prisoners and later universally. Gradually the hours of lighting were extended into the evening, which provided a longer period for reading. Evening school was organized in groups in the dome area of the prison instead of the former individual instruction in cells. A number of other rehabilitative developments took place. Correspondence and visits with family and friends were introduced and later 
expanded along with leisure time activities. The silent system was finally abolished. University correspondence courses were introduced towards the end of this period and several prisoners obtained degrees (MacGuigan, 1977). An emphasis on occupational development was secured through the introduction of workshops and trade training. In short, the importance of social activities was recognized by administrators as crucial to the rehabilitative process (ibid.; also see Cosman, 1981).

From 1960 onwards there was an unparalleled growth in the Canadian Prison System. For example, in the seventy-five year period of 1880 to 1955 the number of prisons in Canada doubled from five to ten; however, in the next twenty year period (1955-1974) this figure rose to fifty-three federal prisons (MacLean, 1986a). Today we have over sixty (Lowman and MacLean, 1991; Canadian Centre for Justice Statistics, 1990.). One of the most important events of this expansionary period was the introduction and refinement of the Therapeutic Community and the expansion of an entire workforce of penal experts in rehabilitation, including prison educators (Lowman and MacLean, 1991; Ekstadt and Griffiths, 1988).

During this period we also see changes in criminological theory, changes which in time gave rise to what is often dubbed 'correctionalism' (MacLean, 1986b). Fundamental to correctionalism is the logic of the 'medical model': the proposition that people who break the law are somehow deficient and require 'correctional' treatment to make them 'normal'. These ideas were certainly not innovative. The Italian criminologist, Cesare Lombroso, developed a theory of crime which suggested that criminals were evolutionary throwbacks who were incapable of functioning in an advanced society because they were biologically inferior. These people could be identified by physical stigmata, usually simian in nature, which was posited as indicative of their inferiority (Vold and Bernard, 1986). The medical model, as it was employed in this theory, suggested the use of physical treatments aimed at making these 'degenerates' normal. Lombrosian theory fell from favour after about forty years and was replaced by a similar one which identified criminal behavior with psychological impairment. People committed crime because their brain did not function properly, and to correct this treatments such as electroconvulsive therapy, prefrontal lobotomies and drug therapy were introduced. These methods and the theoretical perspective which justifies them are still with us today, but they have been supplemented with a theory that locates the source of psychopathology in the social development of the individual (MacLean and Milovanovic, 1991). That is, criminals are seen as people who are deficient in social, moral and cognitive development; thus, in this approach 'treatment' is aimed at correcting these deficiencies. One way by which such rehabilitation might be accomplished is through the 
learning process. This leads to the introduction of educational programs which seek to promote cognitive and moral development so prisoners will leave prison well-equipped to function normally in broader society (Vold and Bernard, 1986).

The idea of post-secondary education in the prison then is not a new one, and during the 1960s and 1970s programs were introduced in a number a prisons in a variety of countries. In Canada, educators at the University of Victoria (UVic) developed a post-secondary educational program for the federal prisons in British Columbia which began operating in 1972. In discussing the aims of this program Douglas Ayers and Stephen Duguid suggest that:

From its inception in 1972, the University of Victoria Program has maintained a commitment to four primary goals:

1. Develop more awareness of the problem and issues in society generally and, hopefully, incorporate more mature values using particularly English and history courses as vehicles for such development.

2. Bring about certain attitude and personality changes that will prepare students to cope successfully with society and its institutions. In particular, develop skill to take alternative views in discussion of issues, to suspend judgement, to understand society's institutions and their rights and responsibilities as citizens.

3. Make students more self-confident and better able to express themselves.

4. Provide students with the basis for further education - vocational, technological, academic or cultural. This basis for continuing education includes the development of the necessary work and study habits and confidence to pursuefurther education. A subsidiary outcome is to make them more employable and better able to hold a job (1980:4).

In order to achieve these goals Ayers and Duguid employed a cognitive development approach based on a developmental model of human growth and maturation attributed to Lawrence Kohlberg, whose work is grounded in the philosophy of John Dewey and the psychology of Jean Piaget. It is assumed that adult prisoners have poorly developed moral reasoning abilities caused by limited opportunities for cognitive development during their socialization. These deficits in reasoning are seen as the criminogenic factors. Prisoners can advance to a higher stage of development through a process of cognitive and moral education. When this is achieved the likelihood that the individual will reoffend is supposedly reduced. Ayers and Duguid developed a complex program which operated on three different yet related levels:

1. The first level of operation was to provide post-secondary education, which was both accredited and transferable to any university in 
Canada. By providing a general education to the level of a Bachelor of Arts degree, it was felt students would be afforded the opportunity for career change.

2. At the second level and because the program is centered on the theory of human development, the program was aimed at providing the cognitive development necessary for social and moral development. Thus a moral/ethical dimension was built into all of the courses, allowing debate and discussion of history for example, from a moral perspective.

3. At the third level the program aimed at creating a sense of an alternate community. This was accomplished by segregating those prisoners in the program from other prisoners in the prison, and by providing an educational staff which were not part of the prison staff (ibid.:5-6).

Despite the questionable theoretical basis for a program which posits that criminal activity results from insufficient cognitive and moral development, the UVic. program (now at Simon Fraser University) can be seen to have noble aims. Clearly a great deal of thought and planning went into the implementation of this pedagogical practice. The question which must be addressed is: How successful was the program?

In order to answer this question, three evaluative tools must be employed. The first identifies what proportion of the prisoner population participated in the program and how many of them completed it. The second assesses observable change in prisoner moral reasoning as suggested by the theory of cognitive and moral development. The third looks for a notable impact on the ex-prisoners' decision to engage in criminal activity.

Concerning the proportion of participation, between 1972 and 1980 hundreds of students participated in the UVic. program. Although only a few of these actually graduated with a degree, the number of prisoners exposed to the program is really quite impressive.

For purposes of evaluating the degree of cognitive and moral development and the impact, if any, this had on criminal activity, Ayers and Duguid conducted an eight-year follow-up study which concluded in 1980. Space does not permit a detailed discussion of the methodology employed; suffice it to say that an experimental group of seventy-three prisoners who had taken at least two terms of classes and who had been released for at least six months was selected and matched with a control group on a number of variables (e.g., age, nature of offence, sentence). The intent was to produce a control group which was similar to the experimental group in all respects but one - participation in the postsecondary educational program. The findings for changes in moral and cognitive development are described by Ayers and Duguid: 
Taken as a whole, the attitude change evidenced in the study indicated a movement away from the moral alienation of the criminal from society and its institution toward an understanding of that society, and the position of the individual (Ibid.).

I would like to illustrate these conclusions by showing you two tables of data produced in this stage of the study.

Table 1: Number and Percent of Respondents' Political Views by Credits Earned

\begin{tabular}{lcccc}
\hline $\begin{array}{c}\text { Credits } \\
\text { Earned }\end{array}$ & \multicolumn{2}{c}{$\begin{array}{c}\text { Increased } \\
\text { Understanding }\end{array}$} & \multicolumn{2}{c}{$\begin{array}{c}\text { Moral } \\
\text { Alienation }\end{array}$} \\
\hline $3.0-12.5$ & $\mathbf{N}$ & $\mathbf{\%}$ & $\mathbf{N}$ & \% \\
$13.5-19.0$ & 1 & 13 & 4 & 50.0 \\
$20.0-28.5$ & 2 & 25 & 2 & 25.0 \\
30 or more & 2 & 25 & 1 & 12.5 \\
Total & 3 & 37 & 1 & 12.5 \\
\hline
\end{tabular}

SOURCE: Adapted from Ayers et al., 1980, Table 10, p. 26.

Although the number of participants $(\mathrm{N})$ is quite small - sixteen in all - the results suggest that with an increase in credits earned the political views of participants were more likely to reflect an increased understanding of society and less moral cynicism. For example, three students with 30 or more credits indicated increased understanding while only one with as many credits was identified as cynical.

Even if we accept the idea that the post-secondary educational program at UVic. had a significant impact on the attitudes of those prisoners exposed to the program - that is, if we accept that there has been an observable development on both cognitive and moral grounds - we cannot simply go on to assume that these changes will automatically be translated into behavioral changes (i.e., less criminal activity). The question then is: to what extent do the cognitive and moral developmental changes contribute to a reduction in criminal behaviour? One way of answering this question is to compare the incidence of observed recidivism in the experimental group with that of the control group. All of the methodological difficulties with both defining and measuring recidivism aside, Ayers and Duguid make just such a comparison: 
Table 2: Number and Percentage of Program Participants and Matched Control Group by Type of Contact with the Law

\begin{tabular}{|c|c|c|c|c|}
\hline \multirow[t]{2}{*}{ Type of Contact } & \multicolumn{2}{|c|}{ Program Participants } & \multicolumn{2}{|c|}{ Control Group } \\
\hline & $\mathbf{N}$ & $\%$ & $\mathbf{N}$ & $\%$ \\
\hline $\begin{array}{l}\text { Return to prison for } \\
\text { violation of parole }\end{array}$ & 2 & 3 & 12 & 18 \\
\hline $\begin{array}{l}\text { Return to prison for } \\
\text { violation of parole } \\
\text { and new offence }\end{array}$ & 4 & 6 & 17 & 26 \\
\hline $\begin{array}{l}\text { Return to prison for } \\
\text { new offence }\end{array}$ & 2 & 3 & 3 & 5 \\
\hline Awaiting trial & 1 & 2 & 2 & 3 \\
\hline $\begin{array}{l}\text { Fines or minor } \\
\text { violations }\end{array}$ & 1 & $<1$ & n.a. & - \\
\hline Not re-incarcerated & 56 & 86 & 31 & 48 \\
\hline Total Group & 65 & 100 & 63 & 100 \\
\hline
\end{tabular}

SOURCE: Adapted from Ayers et al., 1980, Table 26, p. 51.

Once again, the numbers are small, but the trend is notably in favor of Ayers' and Duguid's approach. Of the sixty-five program participants, $86 \%$ were not re-incarcerated. By comparison, $48 \%$ of the control group were not re-incarcerated. It is interesting to note, however, that for both groups very few ( 3 and 5 percent respectively) were returned to prison for new offenses alone. Parole violation seems to be the significant difference.

At this point, it should be asked that with all this emphasis on the efficacy of the UVic. program to improve the level of moral development and thereby reduce the rate of recidivism, is anyone concerned with the value of education itself? Instead of evaluating what students learned (e.g., their grasp of new concepts and their ability to apply and criticize them) assessment is concerned with measuring course work as a curative for pathological conditions. Accepting at face value a theory that criminal activity is linked to the stage of moral development is in itself problematic, at the very least. While we are speaking of morals, one might question how ethical it is to evaluate the worth of teaching history, anthropology, or Canadian literature by their capacity to change a person's perspective towards criminal activity. Who amongst us would like to have our academic achievement assessed on our demonstrated ability to avoid contact with the police? Can such a skill be seen as a valid indicator for educational success either as teacher or student?

Another more subtle problem emerges from the conception of education as a weapon in the arsenal of war against crime. Study after 
study of the prison system in Canada has demonstrated that there is a crisis of control. The parliamentary Sub-Committee, appointed in 1976 to investigate the Canadian Prison system because of the wave of riots, hostage-takings, and other violent disturbances occurring in the 70 s concluded that:

Society has spent millions of dollars over the years to create and maintain the proven failure of prisons. Incarceration has failed in its two essential purposes - correcting the offender and providing permanent protection to society. The recidivist rate of up to $80 \%$ is evidence of both (MacGuigan, 1977).

Many researchers agree that the result has been that the primary objective of the prison administrator is control of the prisoner population (e.g. see Gosselin, 1982). I would like to suggest that the postsecondary educational programs should be seen in the same light: as a strategy of control by prison administrators under the guise of liberal, rehabilitative ideology. Wotherspoon has argued that education in the prison provides an opportunity to increase the surveillance of prisoners:

Education in prison compounds the authority which any educator or educating agency commands over the content and mode of the transmission process. No educational process is neutral, even when couched in the sterile rhetoric of ... liberalism. In prison, the prisoner student is saddled with a potential double handicap of being 'decriminalised' and 'educated' on someone else's terms. The educational enterprise also generates information about the student [prisoner] in the form of grades, progress reports, written documents, and whatever else the [prisoner] reveals through ... educational activities. While educational priorities shift, as they have tended, from an emphasis on content and doing to cognitive and moral development and being-becoming, more aspects of the [prisoner] are opened to scrutiny. The [prisoner's] whole being is increasingly vulnerable to exposure and evaluation. The terms of education become more internal than external; the content becomes less important than self knowledge and the process of education .... [The theory here is that] such a process allows the student working in conjunction with the teacher/ therapist to outgrow certain [sociological pathologies]. Education becomes control ... [And as Gosselin suggests], "the prisoners internalize the desired norms, through a variety of techniques so that they effectively become their own jailers" (1986: 171 emphasis in original).

In short, prisoner eduction posited as moral education is first and foremost an effective form of social control masked as a form of rehabilitation and evaluated not on its pedagogical merit, but on its efficacy of reducing recidivism. That such manipulation of purposes takes place in the prison comes as no surprise to most prisoners. That it should be defended/promoted in the name of moral development is perhaps more disturbing, more draconian than it might otherwise be. 


\section{REFERENCES}

Ayers, D., and S. Duguid. 1980. Effects of University of Victoria Program:A Post Release Study. Ottawa: Correctional Service of Canada, Ministry of The Solicitor General

Canadian Centre for Justice Statistics. 1990. Adult Correctional Services in Canada 19891990. Ottawa: Ministry of Supply and Services

Cosman, J.W. 1981. 'Penitentiary Education in Prison.' L. Morin, ed., On Prison Education. Ottawa: Minister of Supply and Services Canada

Ekstadt, J.W., and C.T. Griffiths. 1988. Corrections in Canada: Policy and Practice, 2 d. ed. Toronto: Butterworths

Gosselin, L. 1982. Prisons in Canada, Montreal: Black Rose Books

Lowman, J., and B.D. MacLean. 1991. 'Prisons and Protest in Canada.' Social Justice, 18 (3): $130-154$

MacGuigan, M. (Chair) Sub-Committee on the Penitentiary System in Canada. 1977. Report to Parliament. Ottawa: Ministry of Supply and Services

MacLean, B.D. 1986a. 'State Expenditures on Canadian Criminal Justice,' B. D. MacLean, ed., The Political Economy of Crime: Readings for a Critical Criminology, 106-133. Toronto: Prentice-Hall

- 1986b. 'Critical Criminology and Some Limitations of Traditional Inquiry,' B. D. MacLean, ed., The Political Economy of Crime: Readings for a Critical Criminology, 1-20. Toronto: Prentice-Hall

MacLean, B.D. and D. Milovanovic. 1991. 'On Critical Criminology,' B. D. MacLean and D. Milovanovic, eds., New Directions in Critical Criminology: Left Realism, Feminism, Postmodernism, Peacemaking, 1-8. Vancouver: The Collective Press

Vold, G.B., and T.J. Bernard. 1986. Theoretical Criminology, 3d. ed. New York: Oxford University Press

Wotherspoon, T. 1986. 'Prison Education and Fiscal Crisis,' B. D. MacLean, ed., The Political Economy of Crime: Readings for a Critical Criminology, 166-176. Toronto: Prentice-Hall. 